\title{
Faktor Permohonan Isytihar Murtad dalam Kalangan Mualaf di Selangor
}

\author{
Suariza@ Hidayah Muhammad \\ Universiti Malaya, hidayahsuariza@gmail.com.my \\ Nor Raudah Hj. Siren \\ Universiti Malaya, raudah68@um.edu.my \\ Yusmini Md Yusoff \\ Universiti Malaya, yusmini@um.edu.my
}

\begin{abstract}
Abstrak
Murtad merupakan satu perkara yang perlu dijauhkan daripada umat Islam. Ini kerana murtad adalah dosa besar yang tidak akan diampunkan Allah. Ini dinyatakan dengan jelas dalam Al-Quran, surah Al-Baqarah ayat 217. Sehubungan itu, Islam mengkategorikan murtad sebagai perbuatan jenayah. Namun, terdapat beberapa definisi dan perbahasan tentang hukuman kepada pesalah murtad. Manakala dalam Perlembagaan Persekutuan, tidak dibincangkan secara jelas tentang murtad, tetapi Perkara 3(1) menyebut tentang kedudukan Islam sebagai agama bagi Persekutuan dan Perkara 11(4) menyatakan Undangundang Negeri dan berkenaan dengan Wilayah Persekutuan Kuala Lumpur, Labuan dan Putrajaya, undang-undang Persekutuan boleh mengawal atau menyekat pengembangan apa-apa doktrin atau kepercayaan agama dalam kalangan orang yang menganuti agama Islam. Dalam konteks penulisan ini, diperincikan mengenai permohonan oleh mualaf untuk diisytiharkan murtad di negeri Selangor. Kajian ini mendapati disebabkan tiada enakmen khusus mengenai perisytiharan murtad maka tiada kes isytihar murtad pernah diputuskan di Selangor.
\end{abstract}

Kata kunci: permohonan murtad, jenayah Syariah, hukuman murtad, Perlembagaan Persekutuan, enakmen di Selangor

\section{Factor of Application for the Declaration of Apostasy Amongst New Mulim Converts in Selangor}

\begin{abstract}
Apostasy must be avoided by Muslims at all costs. This is because apostasy is the most extreme sin that God will not forgive. This is clearly stated in Al-Quran surah Al-Baqarah verse 217. Thus, Islam categorizes apostasy as a crime. But there are some
\end{abstract}


definitions and debates about penalties for apostate offenders. In Malaysia there is no enactment that clearly states about apostasy. When there is an apostasy issue amongst Muslims, they go to the Syariah Court to apply the declaration of apostasy and each state has different laws to deal with this issue. Therefore, this study identifies the process of the declaration of apostasy in the state of Selangor and how the Majlis Agama Islam Selangor addresses this issue. This study finds that since no enactment was related to the apostasy issue, then no apostate declaration application was passed in the state of Selangor.

Keywords: application for apostasy, Syariah crime, penalty for apostate, Federal Constitution, enactment in Selangor

\section{Pendahuluan}

Murtad menurut bahasa Arab berasal daripada perkataan riddah. Dari segi bahasa, riddah bermakna kembali daripada sesuatu kepada selainnya ${ }^{1}$. Dari segi istilah syaraknya pula, murtad ditakrifkan dengan pelbagai takrifan. Al-Jurjāni mendefinisikan murtad atau riddah sebagai "memutuskan Islam dengan niat sama ada dengan niat, percakapan dan perlakuan, sama ada dilakukan secara menghina atau ingkar atau dengan iktikad seperti menafikan kewujudan Allah". Al-Husni menyatakan "keluar daripada Islam dan kembali kepada kufur serta membebaskan diri daripada Islam".3 "Abd al-Qādir 'Awdah mentakrifkan "meninggalkan agama Islam dan keluar daripadanya setelah menganutnya". ${ }^{4}$ Menurut Wahbah al-Zuhaylī murtad bermaksud "berpaling daripada Islam dan kembali kepada kufur, sama ada dengan niat atau perbuatan yang mengkafirkan atau perkataan, dan sama ada diucapkan dengan gurauan atau penentangan atau

1 Muhammad bin Ab̄̄ Bakr bin 'Abd al-Qādir al-Rāzī, Mukhtār al-Ṣihah (Beirut: Maktabah Lubnan, t.t.), 210; Lihat juga Jabran Mas'ud, al-Rā'id (Beirut: Dār al-'Ilm al-Malayīn, 1986), 1: 725-726; Lihat juga al-Fayruz Abādī, al-Qāmūs al-Muhiț (Beirut: Dar Ihya al-Turath al-Arabi, t.t.), 1:570.

2 'Alī bin Muhāmmad bin 'Alī al-Jurjānī, Kitab al-Ta 'rīfāt (t.tp.: Dār al-Nafais, 2003), 180.

3 Taqī al-Dīn Abū Bakr bin Muhammad al-Huṣnī, Kifayāt al-Akhyār fi Hil Ghayāt al-Ikhtiṣār (Beirut: Dār al-Khayr, 1995), 2:493.

4 'Abd al-Qādir 'Awdah, al-Tashrī' al-Jinā' '̄̄ al-Islāmō Muqaranan bi al-Qānūn al-Waḍ 'i (Beirut: Mu'assasah al-Risalah, 1994), 1:661. 
iktikad". Manakala menurut Sayyīd Sābiq beliau mentakrifkan murtad sebagai "kembalinya orang Islam yang berakal dan dewasa ke kekafiran dengan kehendaknya sendiri tanpa ada paksaan dari orang lain. Baik yang kembali itu orang lelaki mahupun orang perempuan"

\section{Metodologi Kajian}

Kajian ini merupakan kajian berbentuk kualitatif, menggunakan metode temu bual semi struktur untuk mendapatkan keterangan daripada pihak pelaksana yang terlibat dalam permohonan pengisytiharan murtad. Dalam kajian ini, menggunakan kaedah persampelan perposive ${ }^{7}$. Pemilihan sampel ini amat baik atau sesuai dalam kajian kualitatif kerana sampel yang dipilih mempunyai maklumat yang ingin diketahui oleh penyelidik iaitu bagi mengenal pasti faktor berlakunya permohonan murtad dan bagaimana proses permohonan pengisytiharan murtad berlaku di Selangor. Informan yang terlibat ialah pemohon pengisytiharan murtad dan Peguam Syarie Majlis Agama Islam Selangor. Sampel ini dipilih bagi mendapatkan data yang tepat dan menjawab persoalan kajian. Temu bual dilakukan untuk mendapatkan datadata penting, tentang proses permohonan pengisytiharan murtad. Justeru, kaedah temu bual adalah penting dalam sesuatu kajian ilmiah dan merupakan salah satu kaedah bagi mendapatkan maklumat yang sahih lagi benar serta diperlukan dalam kajian. ${ }^{8}$

\section{Perbahasan Murtad}

Al-Husnī menyatakan "keluar daripada Islam dan kembali kepada kufur serta membebaskan diri daripada Islam"'. "Abd al-Qādir 'Awḍah mentakrifkan "meninggalkan agama Islam dan keluar

5 Wahbah al-Zuhaylī, al-Fiqh al-Istāmī wa Adillatuh (Damsyik: Dār al-Fikr, 1989), 6:183.

6 Sayyid Sabiq, Fikih Sunnah (Kuala Lumpur: Victory Agencie, 1990), 9:159.

7 Ghazali Darulsalam dan Sufean Hussin, "Metodologi Penyelidikan dalam Pendidikan Amalan dan Analisis Kajian" (Kuala Lumpur: Penerbit Universiti Malaya, 2016), 432.

8 Koentjaraningrat, Metode Wawancara, dalam Koentjaraningrat et. al (ed), Metode-metode Penelitian Masyarakat (cet.1, Jakarta: Penerbit PT Gramedia, 1997), 162.

9 Al-Huṣnī, Kifayāt al-Akhyār fi Hil Ghayāt al-Ikhtiṣār, 2:493. 
daripadanya setelah menganutnya". ${ }^{10}$ Menurut Wahbah al-Zuhaylī murtad bermaksud "berpaling daripada Islam dan kembali kepada kufur, sama ada dengan niat atau perbuatan yang mengkafirkan atau perkataan, dan sama ada diucapkan dengan gurauan atau penentangan atau iktikad". ${ }^{11}$ Manakala menurut Sayyīd Sābiq mentakrifkan murtad sebagai "kembalinya orang Islam yang berakal dan dewasa ke kekafiran dengan kehendaknya sendiri tanpa ada paksaan dari orang lain. Baik yang kembali itu orang lelaki mahupun orang perempuan.

Murtad menurut Mạ̣mūd 'Abd al-Raḥman, riddah ialah melakukan perkara-perkara yang dengannya terkeluar daripada Islam sama ada secara pertuturan, iktikad atau ragu-ragu terhadap sesuatu yang berkaitan Islam yang kadang-kadang terjelma dengan perbuatan."12

Murtad dari segi istilah bermaksud keluar daripada agama Islam sama ada melalui perbuatan, perkataan atau iktikad. ${ }^{13}$ Oleh itu, murtad bermaksud seseorang yang kembali kepada kekufuran setelah menerima Islam. ${ }^{14}$

Seseorang atau sesuatu kumpulan boleh menjadi murtad dengan mempersekutukan Allah sama ada melalui iktikad, ucapan ataupun perbuatan, mengingkari agama Islam atau salah satu rukun padanya, atau mengingkari salah satu hukum Islam yang jelas dan sahih, atau orang yang beriktikad bahawa tidak wajib berhukum dengan hukum yang diturunkan oleh Allah. Terdapat juga pandangan yang mengatakan bahawa seseorang Islam juga dianggap murtad sekiranya, ia mencampakkan al-Quran, mencerca

10 'Awdah, al-Tashrī' al-Jinā'̄ al-Islāmī Muqaranan bi al-Qānūn al-Waḍ' '̄, $1: 661$.

11 Al-Zuhaylī, al-Fiqh al-Islāmī wa Adillatuh, 6:183.

12 Mạ̣mūd 'Abd al-Raḥman 'Abd al-Mun'īm, Mu 'jam al-Muṣtalahạat wa al-Alfāz al-Fiqhiyyah (t.tp.: Dār al- Faḍilah, t.t), 2:140.

13 Mohamed Azam Mohamed Adil, "Undang-undang Murtad: Suatu Penilaian dari Perspektif Fiqh dan Undang-Undang di Malaysia dalam Kanun", Jurnal Undang-undang Malaysia (Mac 1997), 9 Kanun (1) 1-3; Paizah Hj Ismail. Undang-undang Jenayah Islam (Kuala Lumpur: Angkatan Belia Islam, 1991), 244; Mahfodz Mohamad, Jenayah dalam Islam: Suatu Kajian Ilmiah Mengenai Hukum-hukum Hudud (Kuala Lumpur: Nurin Enterprise, 1993), 123-129.

14 'Alī 'Abd al-Hamīd al-Bultajī, Al-Mu'tamad fì al-Fiqh al-Imām Ahmad, (Beirut: Dār al-Fikr, 1995), 300. 
Rasul SAW, menafikan kefarduan solat, zakat atau dengan sengaja minum arak dan terlibat dengan perbuatan zina ${ }^{15}$.

Melihat kepada beberapa takrifan murtad dalam kalangan para ulama, maksud asal murtad adalah tidak berbeza iaitu tidak percaya, yakin, beriman kepada Allah sama ada dalam hati, fikiran, dinyatakan melalui kata-kata ataupun dilakukan dengan perbuatan. Sekiranya tiga perkara ini dilakukan secara jelas dan terang maka keluarlah seorang Muslim daripada menganut Islam.

\section{Murtad di Malaysia}

Sehingga kini di Malaysia tiada sebarang peruntukan dalam perlembagaan Malaysia yang memperuntukkan satu rang undangundang sama ada dalam bentuk melarang atau membenarkan seseorang yang beragama Islam untuk menukar agama (murtad) ${ }^{16}$. Ini menunjukkan bahawa Malaysia menganggap tidak akan berlakunya murtad dalam kalangan orang Islam di Malaysia. Namun begitu gejala murtad berlaku disebabkan faktor yang pelbagai dan keadaan ini memaksa organisasi yang terlibat menghadapi dan menangani masalah murtad sama ada golongan Islam asal atau mualaf.

Pengesahan kepada kejadian murtad yang berlaku berdasarkan kepada pengakuan tertuduh, iaitu seseorang yang telah murtad telah merujuk kepada Jabatan Pendaftaran Negara untuk urusan pertukaran namanya kepada nama yang baru. Pertukaran nama tersebut dibuat berasaskan pemohon tadi telah bertukar agama (murtad) dan inginkan namanya yang baru bersesuaian dengan agamanya yang baru. Menurut perundangan Islam, pengakuan yang dibuat oleh pemohon yang ingin bertukar nama kerana bertukar agama (murtad) merupakan perkara yang boleh disabitkan bahawa pemohon itu telah murtad dari Islam ${ }^{17}$.

15 Mohamed Azam Mohamed Adil, "Hak Tukar Agama dalam Perlembagaan: Konflik Kebebasan Beragama dan Hukum Islam", Jurnal Syariah 11, No. 1 (2003), 29.

16 "Tiada Peruntukan Gubal Undang-undang Murtad", Utusan Malaysia, 22 Januari 1998, (Kenyataan Abdul Hamid Othman kepada pihak akhbar tentang undang-undang murtad), 14.

17 Menurut perundangan Islam, dalam menghukum dan mensabitkan bahawa seseorang itu telah murtad dari Islam, maka terdapat dua cara pembuktian dibuat iaitu: pertamanya melalui pengakuan tertuduh dan keduanya melalui 
Namun demikian, terdapat peruntukan kesalahan keluar agama Islam diguna pakai di beberapa buah negeri. Sebagai contoh, Melaka telah memperuntukkan kesalahan keluar dari agama Islam sebagai satu kesalahan ${ }^{18}$. Seksyen 66 (1) Enakmen Kesalahan Syariah (Melaka) 1991 menyatakan bahawa apabila seseorang Islam dengan sengaja mengaku hendak keluar dari Agama Islam atau mengisytiharkan dirinya sebagai orang yang bukan Islam, Mahkamah boleh memerintahkan orang itu supaya ditahan di Pusat Bimbingan Islam untuk tempoh tidak melebihi enam bulan dengan tujuan pendidikan dan orang itu diminta bertaubat mengikut hukum syarak.

Jika seseorang telah bertaubat, maka taubatnya itu mestilah disahkan di Mahkamah dan kemudian barulah dia boleh dibebaskan. Jika pula seseorang itu bertaubat semasa dalam tahanan, Pegawai Penjaga hendaklah melaporkan perkara itu kepada mahkamah dan taubatnya juga perlu disahkan oleh Mahkamah. Seksyen 6 (1) pula memperuntukkan seseorang yang bersubahat di bawah seksyen 66 adalah merupakan suatu kesalahan dan apabila disabitkan kesalahan tersebut boleh dikenakan hukuman denda tidak lebih daripada lima ribu ringgit atau dipenjarakan selama tempoh tidak melebihi tiga puluh enam bulan atau kedua-dua nya sekali.

Perbincangan agama Islam dalam Perlembagaan Persekutuan sering menjadi kontroversi dalam kalangan masyarakat khususnya pada dekad 90-an dan milenium. Isu yang menggugat kedudukan Islam di Malaysia mula dibangkitkan melalui saluran perundangan. Ini dapat ditunjukkan melalui beberapa kes yang menjadi perbahasan masyarakat seperti Azlina Jailani, Kamariah Ali, Muhammad Abdullah @ Moorthy, desakan meminda atau memansuhkan perkara 121 (1A) Perlembagaan Persekutuan, cadangan penubuhan Interfaith Commission of Malaysia (IFC), penubuhan kumpulan pendesak hak kebebasan beragama yang dikenali sebagai Article 11 dan lain-lain ${ }^{19}$.

keterangan saksi. Lihat Abu 'Abd Allāh Ibn Qudamah, Al-Mughnī (Mesir: Maktabah al-Qāhirah, 1969), 9:18.

18 Di Perlis, satu Rang Undang-undang Perlindungan Aqidah Islam (Perlis) 2000 mengenakan hukuman rehabilitasi selama tidak lebih satu tahun sekiranya didapati cuba menukar agama Islam.

19 Nazri Muslim, Islam dan Melayu dalam Perlembagaan, Tiang Seri Hubungan Etnik di Malaysia (Bangi: Universiti Kebangsaan Malaysia, 2014), 21. 
Perlembagaan Malaysia ada menyatakan dalam Perkara 3(1) Perlembagaan menyebut;

Islam ialah agama bagi Persekutuan; tetapi agama-agama lain boleh diamalkan dengan aman dan damai di mana-mana bahagian Persekutuan ${ }^{20}$.

Manakala Perkara 11(4) Perlembagaan Persekutuan menyebut:

Undang-undang Negeri dan berkenaan dengan Wilayah wilayah Persekutuan Kuala Lumpur, Labuan dan Putrajaya, undang-undang Persekutuan boleh mengawal atau menyekat pengembangan apa-apa doktrin atau kepercayaan agama di kalangan orang yang menganuti agama Islam ${ }^{21}$.

Perlembagaan Malaysia telah menjaga akidah orang Islam dengan meletakkan agama Islam sebagai agama Persekutuan yang meliputi Wilayah wilayah Persekutuan Kuala Lumpur, Labuan dan Putrajaya. Selain itu juga melalui perundangan boleh menyekat mana-mana fahaman kepada orang Islam iaitu ajaran sesat ataupun ajaran yang bertentangan dengan Islam. Ia juga merujuk kepada ajaran selain daripada agama Islam, seperti ajaran Kristian, Hindu mahupun Buddha. Maka tindakan undang-undang boleh dikenakan kepada mereka yang menyampaikan dakyah agama selain Islam kepada orang Islam.

Murtad di Malaysia secara umumnya telah dijaga dan dipandang serius oleh kerajaan Malaysia ia terbukti dengan adanya muzakarah berkenaan perkara yang berkaitan dengan akidah umat Islam di Malaysia dengan mengeluarkan hukum yang jelas melalui Muzakarah Jawatankuasa Fatwa Majlis Kebangsaan Bagi Hal Ehwal Ugama Islam Malaysia. Maka umat Islam wajib untuk mengikut setiap hukum yang telah dikeluarkan oleh majlis tersebut.

\section{Permohonan Isytihar Murtad di Selangor}

Menurut Zulkifli Hasan tiada enakmen perundangan yang jelas mengenai bagaimana untuk berurusan dengan permohonan isytihar murtad atau orang yang mahu menukar agama. Meskipun tiada

${ }^{20}$ Perlembagaan Persekutuan, Hingga 10 Oktober 2014, (International Law Books Servis, 2014), 26.

21 Perlembagaan Persekutuan, Hingga 10 Oktober 2014, (International Law Books Servis, 2014), 39. 
kelulusan yang direkodkan di negeri Selangor, ia tetap merupakan satu isu kritikal yang perlu diberi perhatian. Ini kerana kegagalan memberi pendidikan, bimbingan, pendekatan yang sepatutnya menjadikan penambahan berlakunya gejala murtad dalam kalangan mualaf, hasil kajian yang lepas menunjukkan bahawa fenomena murtad di Malaysia berlaku peningkatan tahun demi tahun $^{22}$.

Seksyen 4-8 Enakmen Jenayah Syariah (Selangor) 1995 dan seksyen 3-6 Akta Jenayah Syariah (Wilayah Persekutuan) 1997 memperuntukkan kesalahan berhubungan dengan akidah yang merangkumi pemujaan ${ }^{23}$, mendakwa orang bukan Islam untuk mengelakkan tindakan ${ }^{24}$, takfir atau mengatakan mana-mana orang Islam adalah kafir ${ }^{25}$, doktrin palsu ${ }^{26}$ dan dakwaan palsu ${ }^{27}$. Terdapat beberapa kes yang dilaporkan di dalam jurnal hukum seperti Pendakwa Mahkamah Syariah Perak v Shah Pandak Othman (1991) 8 JH 99 dan Akbar Ali v Majlis Agama Islam (1996) $10 \mathrm{JH}$ 197.

Isu ini boleh dikatakan dampak dari kegagalan orang Islam di negara ini mendakwahkan dan mentarbiahkan mereka menjadi salah satu penyebab mengapa mereka kembali ke agama asal. Maka usaha dakwah dan tarbiah perlu ditingkatkan, seorang yang memeluk Islam tidak wajar dibiarkan dan tidak diberi apa-apa bimbingan selepas mereka masuk menjadi orang Islam. Jika tidak, besar sekali kemungkinannya permohonan isytihar murtad dalam kalangan mereka akan semakin berterusan dan membimbangkan umat Islam. Walaupun mereka telah mengetahui bahawa hukum murtad itu merupakan dosa besar dan menurut jumhur ulama ia

${ }^{22}$ M. N Nur Suriya, "The Phenomenon of Apostasy in Malaysia: A Dtudy of Its Causes from 2003 until 2006" (Dissertation, International of Islamic University Malaysia), 2006.

${ }^{23}$ Boleh didenda tidak melebihi tiga ribu ringgit atau penjara tidak melebihi dua tahun atau kedua-duanya.

${ }^{24}$ Boleh didenda tidak melebihi lima ribu ringgit atau penjara tidak melebihi tiga tahun atau kedua-duanya.

25 Boleh didenda tidak melebihi lima ribu ringgit atau penjara tidak melebihi tiga tahun atau kedua-duanya.

26 Boleh didenda tidak melebihi lima ribu ringgit atau penjara tidak melebihi tiga tahun atau disebat tidak melebihi enam rotan atau kombinasi mana-mana hukuman.

27 Boleh didenda tidak melebihi lima ribu ringgit atau penjara tidak melebihi tiga tahun atau kedua-duanya. 
bukan sahaja dibalas dengan hukuman yang pedih di akhirat, akan tetapi boleh dihukum sebagai jenayah menurut al-Qur'an dan alSunnah $^{28}$.

Berdasarkan statistik berakhir 2011 menurut sumber Jabatan Perdana Menteri, Mahkamah Syariah menerima 863 kes permohonan untuk menukar status agama Islam dari tahun 2000 hingga 2010, pecahan negeri sebagaimana berikut ${ }^{29}$ :

Jadual 1.1: Statistik Bilangan Permohonan

Menukar Status Agama Setiap Negeri

\begin{tabular}{|c|c|c|c|}
\hline Bil & Negeri & Permohonan & Lulus \\
\hline 1 & Sabah & 238 & 67 \\
\hline 2 & Negeri Sembilan & 172 & 33 \\
\hline 3 & Selangor & 99 & - \\
\hline 4 & W. Persekutuan & 56 & 10 \\
\hline 5 & Perak & 47 & 12 \\
\hline 6 & Penang & 36 & 1 \\
\hline 7 & Melaka & 12 & 3 \\
\hline 8 & Pahang & 8 & 7 \\
\hline 9 & Johor & 8 & - \\
\hline 10 & Kedah & 5 & 1 \\
\hline 11 & Perlis & 3 & 1 \\
\hline 12 & Sarawak & 1 & - \\
\hline 13 & Terengganu & 1 & - \\
\hline 14 & Kelantan & - & - \\
\hline & Jumlah & 863 & 135 \\
\hline
\end{tabular}

Sumber: Jabatan Perdana Menteri

Negeri Selangor mencatatkan seramai 99 permohonan untuk murtad dan tidak ada satu pun yang diluluskan, jika dilihat pada angka tersebut adalah tinggi dan menduduki tempat ketiga di

28 Ahmad Mohamed Ibrahim, Pentadbiran Undang-undang di Malaysia (Kuala Lumpur: Institut Kefahaman Islam Malaysia, 1997), 523.

29 Faizal Arif Tajul Ariffin, "Dahulu Mualaf Kini Murtad" (Prosiding Persidangan Antarabangsa Pembangunan Muallaf 2013 (ICMUD), Kolej Universiti Islam Antarabangsa Selangor, Bangi, 2013), 23. 
Malaysia. Statistik tersebut adalah berdasarkan kes yang dipohon. Permasalahan juga timbul kerana terdapat juga kes yang ingin murtad yang tidak dinyatakan permohonan untuk murtad tetapi pada hakikatnya golongan ini telah pun keluar daripada menganut agama Islam. Sebagaimana dalam al-Quran, surah An-Nisā' ayat 137 yang bermaksud:

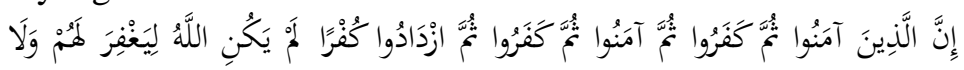

$$
\begin{aligned}
& \text { لِيَهْدِيَهُهْ سَبِيلًا. }
\end{aligned}
$$

Terjemahan: "Sesungguhnya orang yang beriman, kemudian mereka kafir, kemudian mereka beriman semula, kemudian mereka kafir sekali lagi, kemudian mereka bertambah-tambah lagi dengan kekufuran, Allah tidak sekali-kali akan memberi ampun kepada mereka, dan tidak akan memberi petunjuk hidayah kepada mereka ke jalan yang benar".

Allah menyatakan bahawa orang yang sudah beriman dan menjadi kafir dan beriman dan menjadi kafir semula. Malahan kekafirannya semakin bertambah, orang seperti ini tidak akan berkesempatan untuk bertaubat dan dosanya tidak akan diampunkan oleh Allah. Selain itu juga golongan ini tidak akan diberi petunjuk kembali ke jalan yang benar dan diredai oleh Allah. Maka usaha dakwah terhadap golongan ini sukar untuk diberikan kerana tidak dapat mengenal pasti status sebenar agama mereka. Melainkan adanya pengisytiharan keluar dari agama Islam menurut aspek undang-undang syariah.

Kesemua permohonan untuk diisytiharkan keluar daripada Islam melibatkan golongan yang telah memeluk Islam kerana ingin berkahwin dengan pasangan Islam dan pada masa yang sama, pasangan Muslim yang mengahwini mereka jahil tentang Islam, dan pernah bersekedudukan dengan pasangannya sebelum berkahwin serta tidak mendidik pasangannya ${ }^{30}$.

Pada masa yang sama, mereka juga dipulau dan dibuang oleh keluarga asal yang bukan Islam. Mereka hidup sebatang kara dan hanya bergantung dengan pasangan Muslim. Apabila perkongsian hidup menghadapi masalah, bagi membolehkan mereka kembali kepada keluarga asal bukan Islam, mereka perlu kembali kepada

30 Faizal, "Dahulu Mualaf Kini Murtad", 24. 
agama asal mereka. Oleh itu mereka memohon kepada Mahkamah Syariah untuk isytihar murtad ${ }^{31}$.

Golongan yang memilih Islam sebagai agama baru, biasanya mereka akan menghadapi beberapa cabaran dan pengorbanan yang harus ditempuhi, sama ada daripada keluarga mereka sendiri, mahupun dari lingkungan masyarakat yang baru mereka kenal iaitu Islam. Bagi mereka yang kuat imannya dan faham serta menghayati bahawa Islam sebagai agama yang membawa umatnya ke arah yang penuh rahmat dan mendidik manusia untuk tidak melakukan segala kerosakan di muka bumi dan Islam adalah jalan yang paling sempurna dalam semua kehidupan, menjadi haluan yang mengatur semua perjalanan hidup manusia. Maka golongan ini akan terselamat daripada gejala untuk murtad. Tetapi jika sebaliknya yang berlaku tiada kefahaman, penghayatan dan pengamalan terhadap agama yang dianutinya maka keadaan ini yang menyebabkan berlakunya permohonan untuk isytihar murtad.

Menurut Fahimi Madani, Peguam Syarie, MAIS, menyatakan sebenarnya murtad bukanlah suatu "hak" yang boleh dituntut di mahkamah. Amalan yang berlaku di Malaysia dan khususnya di Negeri Selangor ialah pihak-pihak akan membuat tuntutan pengisytiharan bahawa seseorang itu bukan lagi orang Islam (rujuk sek. 61 (3) (x) Enakmen Pentadbiran Agama Islam (Negeri Selangor) 2003$)^{32}$.

Tuntutan ini hendaklah dibezakan dengan tuntutan murtad menurut undang-undang. Ini kerana dari sudut perundangan, murtad dikategorikan sebagai kes jenayah. Dalam kes jenayah, hanya pihak pendakwa yang boleh memulakan prosiding ${ }^{33}$ dakwaan di mahkamah. Mana-mana pihak yang menuduh orang Islam yang lain sebagai telah murtad boleh disabitkan dengan kesalahan "takfir" ${ }^{34}$ di bawah peruntukan seksyen 6 Enakmen

31 Faizal, "Dahulu Mualaf Kini Murtad", 24.

32 Fahimi Mahamad Madani (Peguam Syarie, MAIS), dalam temu bual dengan penulis, 23 Julai 2015.

33 Tindakan Guaman.

34 (1) Tertakluk kepada subseksyen (2), seseorang yang mengatakan atau mengaitkan melalui kata-kata, sama ada secara lisan atau tulisan, atau dengan isyarat, atau dengan gambaran tampak, atau dengan apa-apa perbuatan, kegiatan atau kelakuan, atau dengan mengelolakan, menganjurkan atau mengaturkan apa-apa kegiatan, atau selainnya dengan apa-apa jua cara, bahawa mana-mana orang yang menganuti agama Islam, atau orang-orang 
Jenayah Syariah (Selangor) 1995. Pengecualian hanya diberikan kepada Mahkamah dan pihak berkuasa agama sahaja (rujuk Sek. 6 (2) Enakmen Jenayah Syariah (Selangor) $1995^{35}$.

Oleh kerana permohonan murtad dikategorikan sebagai kes jenayah, maka mereka memohon tuntutan pengisytiharan bahawa mereka bukan lagi orang Islam, di bawah kategori kes "Mal", iaitu sesiapa sahaja boleh memohon di Mahkamah Syariah jika mereka merasakan status agama Islam mereka meragukan atau telah direkodkan secara salah oleh mana-mana agensi awam (Jabatan Pendaftaran Negara (JPN), Jabatan Agama Islam Negeri, Majlis Agama Islam Negeri, dan juga NGO seperti Pertubuhan Kebajikan Islam Malaysia ${ }^{36}$.

Hal ini juga boleh berlaku kepada seorang mualaf yang memeluk agama Islam secara tidak sah atau tidak sempurna menurut hukum syarak dan undang-undang, seperti dipaksa dan diugut untuk memeluk agama Islam. Namun demikian, beban pembuktian untuk mendakwa sedemikian adalah terletak kepada pihak yang menuntut iaitu pihak Plaintif dalam kes tersebut. ${ }^{37}$

yang tergolong dalam mana-mana kumpulan, kelas atau perihalan orang yang menganuti agama Islam: (a) adalah orang kafir; (b) telah berhenti menganuti agama Islam; (c) tidak patut diterima, atau tidak dapat diterima sebagai menganuti agama Islam; atau (d) tidak mempercayai, mengikuti, menganuti atau tergolong dalam agama Islam; adalah melakukan suatu kesalahan dan apabila disabitkan boleh didenda tidak melebihi lima ribu ringgit atau dipenjarakan selama tempoh tidak melebihi tiga tahun atau kedua-duanya. (2) Subseksyen (1) tidaklah terpakai bagi: (a) apa-apa jua yang dilakukan oleh mana-mana Mahkamah atau pihak berkuasa agama yang ditubuhkan, dibentuk atau dilantik melalui atau di bawah mana-mana undang-undang bertulis dan yang diberi oleh undang-undang bertulis kuasa untuk memberikan atau mengeluarkan apa-apa fatwa atau keputusan tentang apa-apa perkara mengenai agama Islam; atau (b) apa-apa jua yang dilakukan oleh mana-mana orang menurut atau mengikut apa-apa fatwa atau keputusan yang diberikan atau dikeluarkan oleh Mahkamah atau pihak berkuasa agama itu, sama ada atau tidak fatwa atau keputusan itu adalah secara bertulis atau, jika bertulis, sama ada atau tidak disiarkan dalam Warta.

35 Fahimi Mahamad Madani (Peguam Syarie, MAIS), dalam temu bual dengan penulis, 23 Julai 2015.

36 Fahimi Mahamad Madani (Peguam Syarie, MAIS), dalam temu bual dengan penulis, 23 Julai 2015.

37 Fahimi Mahamad Madani (Peguam Syarie, MAIS), dalam temu bual dengan penulis, 23 Julai 2015. 
Statistik kes pengisytiharan bahawa seseorang itu bukan lagi orang Islam dari tahun 2011 sehingga 2015 yang diterima oleh Majlis Agama Islam Selangor adalah seperti perincian berikut ${ }^{38}$ :

Jadual 1.2: Statistik Kes Pengisytiharan Murtad

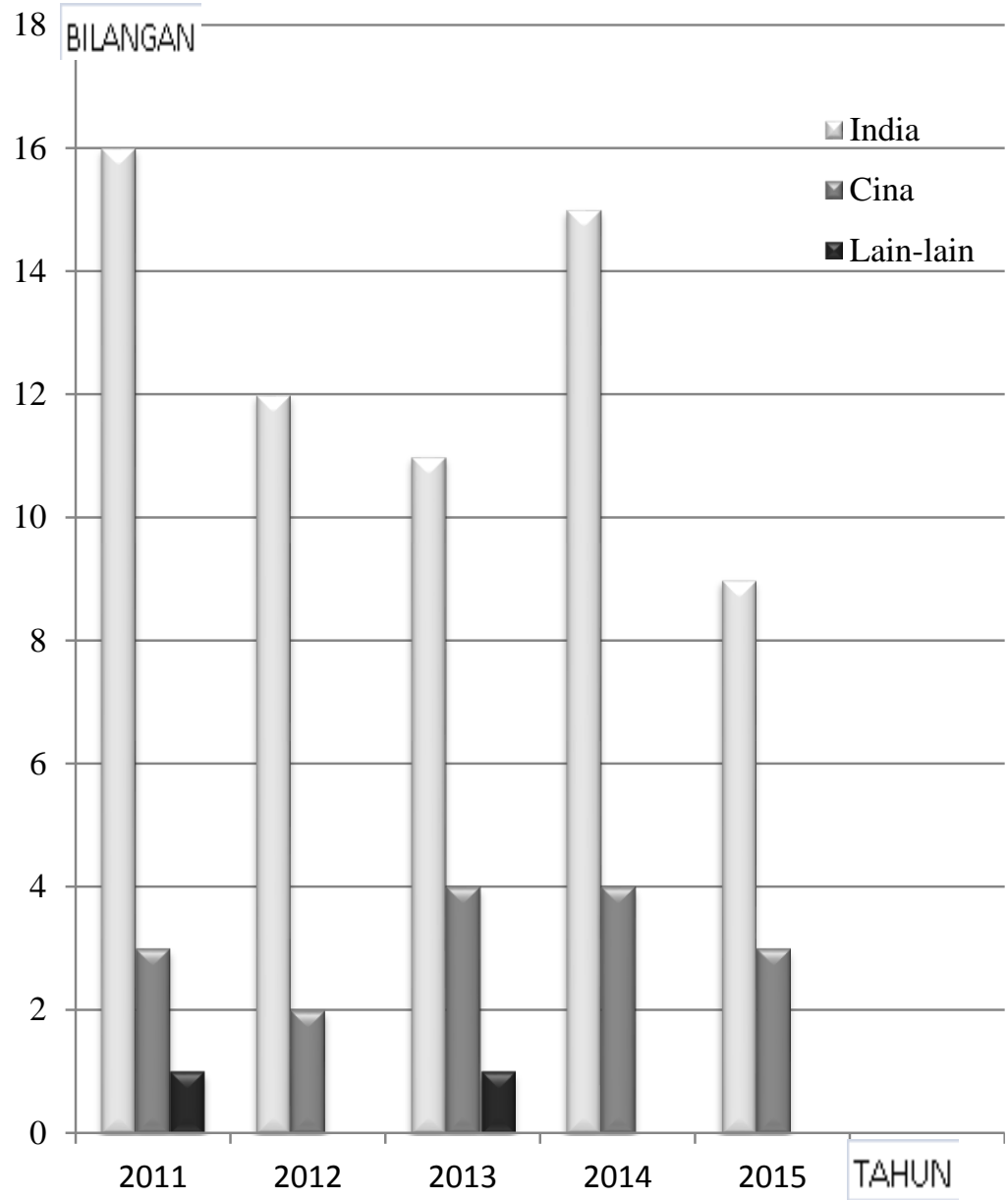

Sumber: Temu bual Bersama Fahimi

Mahamad, Peguam Syarie, MAIS.

38 Fahimi Mahamad Madani (Peguam Syarie, MAIS), dalam temu bual dengan penulis, 23 Julai 2015. 
Jumlah keseluruhan permohonan sejak tahun 2011 sehingga 2015 ialah sebanyak 81 kes, permohonan yang paling banyak ialah bangsa India sebanyak 63 kes, Cina 16 kes dan lain-lain ialah Punjabi 1 kes dan Filipina 1 kes. berikut:-

Terdapat kes yang ditutup disebabkan perkara-perkara

1. Plaintif menarik balik kes.

2. Kes dibuang disebabkan Plaintif tidak hadir ke mahkamah.

3. Bantahan awal pihak Defendan diterima akibat ketidakaturan pemfailan kes dan isu bidang kuasa Mahkamah (isu permastautinan pihak Plaintif) ${ }^{39}$.

Bagi kes pengisytiharan bahawa seseorang itu bukan lagi orang Islam, biasanya pihak Plaintif akan memfailkan Saman dan Pernyataan Tuntutan di Mahkamah Syariah. Dalam Saman tersebut, pihak Plaintif akan menamakan MAIS sebagai pihak Defendan. Jabatan Agama Islam dan Jabatan Pendaftaran Negara juga turut menjadi Defendan ${ }^{40}$.

Setelah itu, Plaintif akan menyerah sampaikan sesalinan Saman dan Pernyataan Tuntutan tersebut kepada pihak MAIS. Pihak MAIS pula akan memfailkan Pembelaan dan Tuntutan Balas selepas menerima Saman daripada pihak Plaintif. Di Selangor, adalah menjadi kebiasaan kepada pihak MAIS untuk memfailkan suatu permohonan Interlokutori ${ }^{41}$ untuk mendapatkan perintah perlaksanaan proses penasihatan akidah selama 6 bulan di Jabatan Mufti Negeri Selangor. Dalam proses ini, Plaintif akan diminta datang ke Jabatan Mufti untuk menjalani proses penasihatan akidah selaras dengan nas syarak iaitu "ad-din itu nasihat"

Justeru itu dapat difahamkan bahawa Institusi yang terlibat dalam proses permohonan pengisytiharan murtad di MAIS ialah Mahkamah Syariah, Jabatan Mufti Selangor dan MAIS sendiri. Secara ringkasnya, boleh dilihat dari carta aliran berikut:

39 Fahimi Mahamad Madani (Peguam Syarie, MAIS), dalam temu bual dengan penulis, 23 Julai 2015.

40 Fahimi Mahamad Madani (Peguam Syarie, MAIS), dalam temu bual dengan penulis, 23 Julai 2015.

41 Permohonan sampingan yang dilakukan daripada permohonan yang asal.

42 Permohonan sampingan yang dilakukan daripada permohonan yang asal. 
Carta 1: Carta Aliran Tuntutan

Pengisytiharan Bukan Beragama Islam

1. Plaintif memfailkan Saman dan Pernyataan Tuntutan di Mahkamah Syariah, dengan menamakan MAIS sebagai Defendan. Plaintif menyerahkan satu salinan Saman kepada MAIS.

2. MAIS memfailkan Pembelaan dan Tuntutan Balas selepas menerima Saman. Biasanya, MAIS memfailkan juga suatu permohonan interlokutori untuk mendapatkan perintah perlaksanaan proses penasihatan akidah selama enam bulan di Jabatan Mufti.

3. Jabatan Mufti melantik Panel Penasihatan Akidah. Dalam kes Mualaf, biasanya panel adalah juga bekas mualaf yang pakar dalam agama dan sebangsa dengan Plaintif agar mudah berinteraksi.

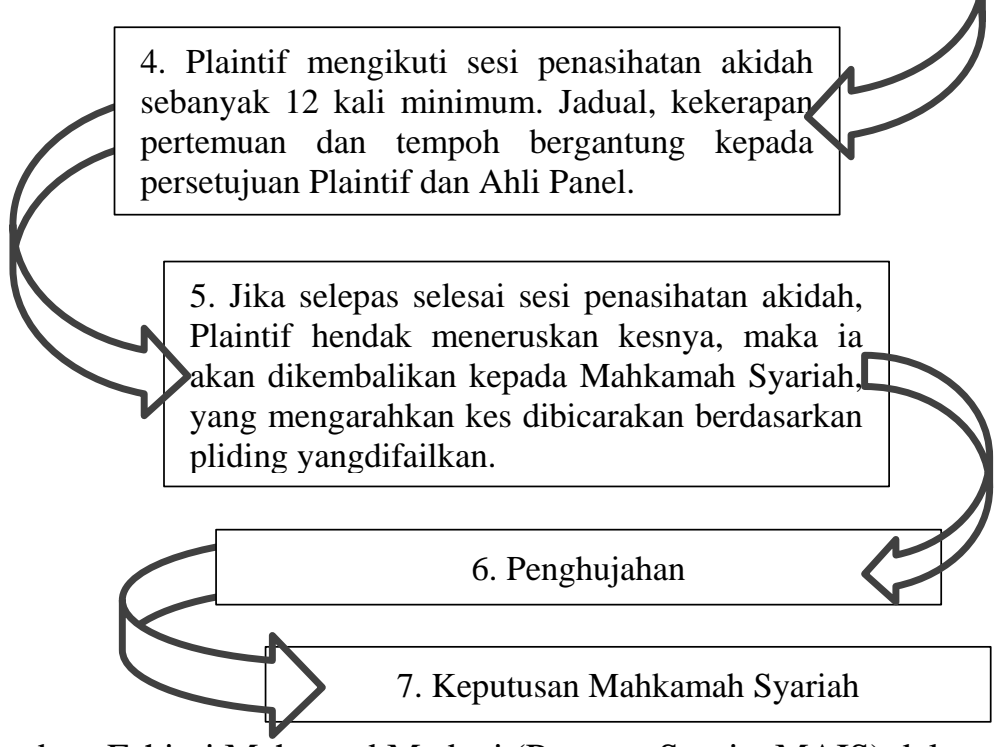

Sumber: Fahimi Mahamad Madani (Peguam Syarie, MAIS) dalam temu bual dengan penulis, 23 Julai 2015 
Pertama, Mahkamah Syariah apabila Plaintif [pemohon] memfailkan Saman dan Pernyataan Tuntutan di Mahkamah Syariah, dalam Saman tersebut, pihak Plaintif akan menamakan MAIS sebagai pihak Defendan. Plaintif akan menyerah sampaikan sesalinan Saman dan Pernyataan Tuntutan tersebut kepada pihak MAIS.

Kedua Majlis Agama Islam Selangor akan memfailkan Pembelaan dan Tuntutan Balas selepas menerima Saman daripada pihak Plaintif. Di Selangor, adalah menjadi kebiasaan kepada pihak Majlis Agama Islam Selangor untuk memfailkan suatu permohonan Interlokutori untuk mendapatkan perintah perlaksanaan proses penasihatan akidah selama 6 bulan di Jabatan Mufti Negeri Selangor.

Ketiga Jabatan Mufti akan melantik mana-mana individu yang berkelayakan untuk mengendalikan sesi tersebut. Individu ini juga dikenali sebagai "Panel Penasihatan Akidah". Bagi kes mualaf, kebiasaannya panel yang dilantik adalah di kalangan pendakwah yang telah memeluk agama Islam, mempunyai pengetahuan yang mendalam dalam ajaran Islam dan berkeupayaan untuk bertutur dengan baik dalam bahasa yang mudah difahami oleh pihak Plaintif.

Keempat plaintif hendaklah mengikuti sesi sebanyak 12 kali secara minimumnya dengan kekerapan sebanyak 2 kali sebulan. Tetapi ia juga bergantung kepada masa Plaintif dan juga ahli panel yang mengendalikan kes ini, sama ada boleh mengikut jadual yang ditetapkan atau tidak. Sekiranya adanya perkara yang tidak dapat dielakkan maka mungkin masa akan dilanjutkan sehingga sesi pertemuan mencukupi sekurang-kurangnya 12 kali.

Kelima selepas menjalani proses ini Plaintif masih mahu meneruskan kesnya maka pendirian pihak Plaintif tersebut akan dipanjangkan kepada pihak mahkamah. Seterusnya, mahkamah akan mengarahkan kes tersebut dibicarakan berdasarkan pliding ${ }^{43}$ yang telah difailkan di mahkamah. Keenam, penghujahan di Mahkamah dan yang ketujuh, keputusan daripada Mahkamah Syariah.

Dalam tempoh enam bulan berjalannya proses penasihatan akidah atau istitabah, Bahagian Pengurusan dan Pembangunan

43 Permohonan rayuan. 
Mualaf Majlis Agama Islam Selangor sukarelawannya ${ }^{44}$ akan mengadakan ziarah kepada pemohon pengisytiharan murtad secara berkala, sebulan sekali pada hari Sabtu dan Ahad ${ }^{45}$.

Sukarelawan ini dipilih berdasarkan komitmen mereka dalam menghadiri kelas dan kursus-kursus agama yang dianjurkan oleh Majlis Agama Islam Selangor dan mereka menunjukkan potensi yang baik untuk menjadi pendakwah. Kriteria ini dipilih supaya memudahkan komunikasi semasa sesi ziarah berjalan. Pihak Majlis Agama Islam Selangor akan memberi garis panduan untuk sesi ziarah. Ziarah pertama kali untuk bertanya khabar, ziarah yang keduanya untuk mengetahui perkembangan kehidupan harian dan yang ketiga bertanyakan tentang status permohonan pengisytiharan murtad yang dipohon. Ziarah seterusnya mengadakan sesi dialog dalam soal ketuhanan dan perbandingan $\operatorname{agama}^{46}$.

\section{Faktor Permohonan Isytihar Murtad di Selangor}

Berdasarkan hasil temu bual kepada sepuluh orang informan faktor berlakunya permohonan pengisytiharan murtad dapat dibahagikan kepada tiga bahagian utama iaitu kegagalan rumah tangga, putus cinta dan desakan keluarga.

\section{Kegagalan Rumah Tangga}

Kegagalan menyebabkan berlakunya permohonan pengisytiharan murtad ini kerana sikap curang yang ditunjukkan oleh isteri pemohon menyebabkan beliau kecewa. Beliau pernah melihat kecurangan isterinya yang berpelukan dengan lelaki lain di dalam kereta. Selain itu juga pemohon menyatakan isteri beliau tidak mengamalkan ajaran Islam iaitu tidak mengerjakan solat dan bergaul bebas dengan lelaki. Ujarnya ${ }^{47}$ :

“...isteri saya curang, saya pernah nampak isteri menaiki kereta dengan seorang lelaki dan berpelukan dengan lelaki

\footnotetext{
44 Sukarelawan MAIS yang melakukan ziarah mereka biasanya adalah dalam kalangan yang memeluk Islam dan benar-benar memahami dan menghayati Islam.

45 Che Mohd Noorlee Abdullah (Eksekutif Unit Pendaftaran dan Pengurusan Rekod Mualaf) dalam temu bual dengan penulis, 2 Febuari 2015.

${ }^{46}$ Che Mohd Noorlee Abdullah, (Eksekutif Unit Pendaftaran dan Pengurusan Rekod Mualaf) dalam temu bual dengan penulis, 2 Febuari 2015.

47 Pemohon Kedua, dalam temu bual dengan penulis, 25 April 2015.
} 
tersebut..isteri saya pun tidak mengamalkan ajaran Islam, isteri tidak mengerjakan solat, bergaul dengan lelaki secara bebas".

Pemohon keenam juga gagal dalam rumah tangganya, dia kecewa dengan sikap isterinya yang cemburu, menyebabkan mereka bercerai dan membawa kepada permohonan murtad. Sikap cemburu isteri menjadikan beliau tidak selesa, mula rasa rimas dan bosan. Baginya isteri tidak memahami dirinya yang mempunyai ramai kenalan kawan perempuan dan mereka hanya rakan sekerja sahaja. Tetapi isteri seolah-olah tidak dapat menerimanya dan mengatakan beliau mempunyai hubungan sulit dengan kawan perempuannya, sedangkan beliau hanya berkawan sahaja. Pemohon menjelaskan;

“.... sikap terlalu cemburu isteri terhadap saya, membuatkan saya terlalu rimas dan bosan dengan keadaan ini. Isteri tidak memahami saya dan dia tidak boleh bersabar dengan saya, yang ramai kenalan perempuan. Sedangkan kawan perempuan adalah rakan sekerja sahaja, isteri kata saya ada hubungan sulit dengan kawan perempuan saya..saya kawan saja" ${ }^{\circ 8}$.

Perkara yang sama berlaku kepada Pemohon Ketujuh yang kecewa dengan sikap curang suami selepas dua tahun berkahwin dengannya suami beliau ada hubungan sulit dengan perempuan lain. Hancur hati pemohon kerana suami tidak setia dan mensiasiakan cintanya. Perasaan benci pada suaminya kerana suaminya curang menduakan dirinya. Segala pengorbanan beliau tidak bererti buat suaminya. Disebabkan hal ini pemohon bercerai dan memohon untuk pengisytiharan murtad. Pemohon memberitahu bahawa:

"Saya tidak sangka suami sanggup menduakan saya, kami baru berkahwin dua tahun dan dia dah ada kekasih hati yang lain... Saya sangat bencikan dia, saya bercerai dan mahu murtad" ${ }^{\prime 4}$.

Setiap pasangan yang berkahwin perlukan perhatian dan sokongan dari pasangan masing-masing. Namun begitu pemohon kecewa kerana suaminya mengabaikannya. Selepas berkahwin hidupnya dengan suami tidak seperti yang diharapkan. Suami telah

48 Pemohon Keenam, dalam temu bual dengan penulis, 26 April 2015.

49 Pemohon Ketujuh, dalam temu bual dengan penulis, 9 Mei 2015. 
meninggalkan beliau hidup bersama dengan mertuanya di tempat yang berjauhan dengan suami. Sebagai pasangan suami isteri mereka tidak hidup sebumbung. Beliau tidak sanggup lagi menanggung penderitaan disebabkan sikap suami terhadap dirinya. Baginya suami telah menganiya dan melakukan kezaliman terhadap dirinya. Sehingga menyebabkan dia bercerai dengan suami dan memohon untuk pengisytiharan murtad. Menurutnya:

"Selepas saya berkahwin dengan suami kehidupan tidak seperti yang diharapkan. Suami saya tinggalkan saya hidup bersama maknya dan dia kerja di tempat lain. Saya tidak dapat hidup bersama dengan suami... Saya sudah tidak tahan lagi menanggung penderitaan ini. Suami tak bagi duit belanja pada saya, mak dia layan saya teruk maki hamun saya. Perbuatan yang dilakukan oleh suami saya kepada diri saya adalah satu penganiayaan dan bersifat zalim. Sebab itu saya telah membuat keputusan untuk bercerai dengan suaminya dan keluar dari agama Islam"50.

Pemohon Kesepuluh, mengalami perkara yang sama, kecewa dengan sikap pasangannya, apabila isterinya tidak faham apa yang diperlukan olehnya. Isterinya juga selalu melawan dan membantah beliau. Kesannya mereka sering bergaduh, dia memaklumkan bahawa:

"Isteri saya tidak faham apa yang saya mahu, dia selalu tidak dengar cakap dan melawan apa yang saya cakap. Selalu bergaduh dengan saya, saya sudah tidak tahan dengan dia" ${ }^{\text {. }}$.

\section{Putus Cinta}

Seterusnya disebabkan putus cinta terjadinya permohonan pengisytiharan murtad. Apa yang berlaku kepada pemohon kelima apabila teman lelakinya yang beragama Islam tidak jadi mengahwininya setelah dia memeluk Islam. Keputusan beliau untuk memeluk Islam kerana ingin berkahwin dengan teman lelakinya menunjukkan dia memeluk Islam kerana cintanya kepada kekasihnya. Perkahwinan yang dirancang tidak kesampaian dan dia kecewa. Walaupun beliau telah belajar agama Islam demi untuk perkahwinannya dengan kekasihnya, tetapi kekasihnya tetap memutuskan hubungan percintaan mereka. Oleh

50 Pemohon Keempat, dalam temu bual dengan penulis, 26 April 2015.

51 Pemohon Kesepuluh, dalam temu bual dengan penulis, 10 Mei 2015. 
sebab itu, pemohon membenci kekasihnya. Ini kerana kekasih pemohon membuat keputusan untuk berkahwin dengan calon isteri yang telah dipilih oleh kedua ibu bapanya. Pemohon bukan sekadar kecewa dengan teman lelakinya tetapi juga kecewa dengan agama Islam sebab itu beliau telah memohon pengisytiharan untuk murtad:

"Kekasih saya, telah memberitahu saya bahawa dia tidak boleh berkahwin dengan saya kerana kedua ibu bapanya telah mencari calon isteri untuknya...terpaksa membatalkan rancangan untuk berkahwin dengan saya. Dia tidak mahu jadi anak yang derhaka dia terpaksa berkahwin dengan calon isteri pilihan ibu bapanya. Selepas saya memeluk Islam dan mempelajari agama Islam bagi memenuhi tuntutan untuk hidup sebagai seorang muslim..saya benci sangat sebab tu saya nak murtad" 52 .

Begitu juga dengan Pemohon Ketujuh yang kecewa dengan sikap kekasihnya yang tidak menepati janji. Beliau mengimpikan kehidupan sebagai suami isteri bersama kekasihnya tetapi kekasih beliau telah memutuskan hubungan cinta mereka selepas pemohon memeluk Islam. Kekasihnya telah berjanji untuk menjadikan beliau sebagai isteri tetapi akhirnya menghilangkan diri entah ke mana, keadaan ini menyebabkan pemohon hilang kepercayaan kepada kekasihnya dan memohon untuk murtad. Beliau menyatakan bahawa:

"Saya sangat kecewa dan kekasih saya, saya sangat cinta pada dia sehingga saya sanggup masuk Islam demi untuk bersama dengannya. Tetapi selepas saya masuk Islam dia pula pergi tinggalkan saya, saya tidak tahu dia pergi ke mana, telah berjanji untuk berkahwin dengan saya, tetapi selepas itu dia hilang, saya tidak percayakan dia, saya mahu kembali ke agama asal saya" ${ }^{, 53}$.

Pemohon Ketiga merasakan hidupnya kosong, sunyi dan sepi apabila suaminya telah meninggal dunia. Beliau sangat sedih dengan kematian suaminya, disebabkan hal ini dia mahu keluar dari Islam dan mengikut agama sebelumnya:

52 Pemohon Kelima, dalam temu bual dengan penulis, 26 April 2015.

53 Pemohon Ketujuh, dalam temu bual dengan penulis, 9 Mei 2015. 
"Selepas suami saya meninggal dunia, saya sedih sangat, hidup saya sunyi dan saya mahu kembali kepada agama asal saya..saya masuk Islam pun sebab ikut suami saja".

Begitu juga apa yang terjadi kepada Pemohon Kesembilan, selepas kematian suaminya hidupnya menjadi sunyi dan dia sedih dengan kehilangan suami buat selama-lamanya. Oleh sebab itu dia mahu isytihar keluar agama Islam dan kembali kepada agama asalnya:

"Saya masuk Islam sebab ikut agama suami.. lepas suami saya meninggal dunia, saya sedih sangat, hidup saya sunyi dan saya mahu kembali kepada agama asal saya, ${ }^{, 54}$.

Bagi Pemohon Ketiga dan Pemohon Kesembilan tiada sebarang alasan yang kukuh untuk mereka terus menjadi seorang Islam apabila suami mereka meninggal dunia kerana sebab utama mereka memeluk Islam adalah kerana mengikut suami masingmasing.

\section{Keluarga}

Desakan keluarga menyebabkan permohonan pengisytiharan murtad berlaku. Pemohon mengakui bahawa dia masih di bawah jagaan kedua ibu dan bapanya. Kebergantungan kepada kedua ibu bapanya sangat perlu kepada beliau untuk meneruskan keperluan kehidupannya dalam segala aspek terutamanya dalam keperluan kewangan. Jelas pemohon:

"Saya masih lagi dalam jagaan dan kawalan kedua ibu bapa, segala gerak-geri dan perilaku serta perbelanjaan adalah dikawal dan ditanggung oleh bapa saya..saya kena ikut family saya sebab tu saya nak murtad..."

Begitu juga sekiranya diteliti laporan kes permohonan keluar Islam di dalam jurnal undang-undang sama ada di Mahkamah Sivil ataupun di Mahkamah Syariah, kebanyakannya difailkan oleh golongan mualaf ${ }^{56}$, seperti 21 kes permohonan keluar agama yang melibatkan mualaf, permohonan yang diuruskan oleh Tetuan

54 Pemohon Kesembilan, dalam temu bual dengan penulis, 9 Mei 2015.

55 Pemohon Pertama, dalam temu bual dengan penulis, 25 April 2015.

56 Sia Kwee Hin lwn. JAIWP [1992] 2 CLJ, 1-4; Lim Yoke Khoon lwn. Pendaftar Muallaf, Majlis Agama Islam Selangor \& Yang Lain [2006] 4 CLJ, 513-526; Majlis Agama Islam Pulau Pinang lwn. Siti Fatimah Tan binti Abdullah [1430H] JH 27/2; Sumanthi a/p maniam lwn. Majlis Agama Islam Wilayah Persekutuan (1434H) JH36/1, 143-159. 
Tengku Azlina dan Azman bagi Majlis Agama Islam Wilayah Persekutuan Kuala Lumpur ${ }^{57}$. Antara faktor yang menyebabkan golongan ini membuat permohonan keluar Islam di Mahkamah Syariah adalah kerana kecewa dengan kehancuran rumahtangga mereka ${ }^{58}$, tiada bimbingan mengenai ajaran Islam $^{59}$ dan tiada tempat bergantung setelah memeluk Islam ${ }^{60}$.

Perkara ini dapat dilihat dalam kes Wong Chun Chiak @ Kenny Abdullah lawan Majlis Agama Islam Wilayah Persekutuan. Mahkamah Syariah telah mengetepikan permohonan keluar agama beliau. Kenny seorang mualaf membuat permohonan keluar agama kerana ingin berkahwin dengan orang bukan Islam dan ingin kembali kepada agama asal, iaitu Kristian Roman Katolik ${ }^{61}$.

\section{Penutup}

Jelasnya isu murtad adalah sesuatu yang perlu ditangani secara konsisten dan teratur. Semua agensi yang berkaitan dan masyarakat perlu bersama-sama dalam membanteras masalah permohonan isytihar murtad sama ada dalam kalangan Islam asal atau pun dalam kalangan mualaf. Dengan adanya usaha bersepadu semua pihak dalam membanteras gejala murtad dapat mengurangkan permohonan isytihar murtad di Malaysia. Oleh yang demikian kefahaman secara jelas berkenaan murtad perlu dimaklumkan kepada semua lapisan masyarakat bagi membendung gejala murtad daripada terus merebak.

57 Dokumen rasmi, Permohonan Keluar Agama Islam (Mualaf), Tetuan Tengku Azlina, Azlan Shah dan Azman, Peguambela \& Peguamcara, Peguam Syarie, Bandar Tun Razak, Cheras, Kuala Lumpur, Januari 2015, 1-6.

58 Mohd Ridhuan Tee Abdullah, Cabaran Saudara Baharu di Malaysia (Kuala Lumpur: Utusan Publication \& Distributor Sdn. Bhd., 2012), 38; Ann Wang Seng, Murtad Jangan Pandang Sebelah Mata (Kuala Lumpur: Mustread Sdn. Bhd., 2009), 127.

59 Mohd Ridhuan Tee Abdullah, Cabaran Saudara Baharu di Malaysia, 39.

${ }^{60}$ Ann Wan Seng, Murtad Jangan Pandang Sebelah Mata, 126.

61 "Mahkamah Ketepi Permohonan Keluar Islam", Utusan Malaysia, 31 Ogos 2006, 14. 


\section{Rujukan}

'Abd al-Mun'īm, Mạ̣mūd 'Abd al-Raḥman. Mu'jam alMuștalahāt wa al-Al-fāz al-Fiqhiyyah. T.tp.: Dār al- Faḍilah, t.t. 'Awdah, 'Abd al-Qādir. Al-Tashrī' al-Jinā' '̄ al-Islāmī Muqaranan bi al-Qānūn al-Waḍ' 'i. Beirut: Mu'assasah al-Risalah, 1994.

"Mahkamah Ketepi Permohonan Keluar Islam", Utusan Malaysia, 31 Ogos 2006, 14.

"Tiada Peruntukan Gubal Undang-undang Murtad", Utusan Malaysia, 22 Januari 1998, (Kenyataan Abdul Hamid Othman kepada pihak akhbar tentang undang-undang murtad), 14.

Abādī, al-Fayruz. Al-Qāmūs al-Muhit (Beirut: Dar Ihya al-Turath al-Arabi, t.t.), 1:570.

Al-Bultajī, 'Alī 'Abd al-Hamīd. Al-Mu'tamad fì al-Fiqh al-Imām Ahmad. Beirut: Dār al-Fikr, 1995.

Al-Huṣnī, Taqī al-Dīn Abū Bakr bin Muhammad. Kifayāt alAkhyār fi Hil Ghayāt al-Ikhtișār. Beirut: Dār al-Khayr, 1995.

Al-Jurjān̄̄, 'Alī bin Muḥāmmad bin 'Alī. Kitab al-Ta 'rîfāt. T.tp.: Dār al-Nafais, 2003.

Al-Rāzī, Muḥammad bin Ab̄̄ Bakr bin 'Abd al-Qādir. Mukhtār alSihah. Beirut: Maktabah Lubnan, t.t.

Al-Zuhaylī, Wahbah. Al-Fiqh al-Islāmī wa Adillatuh. Damsyik: Dār al-Fikr, 1989.

Ann Wang Seng, Murtad Jangan Pandang Sebelah Mata. Kuala Lumpur: Mustread Sdn. Bhd., 2009.

Che Mohd Noorlee Abdullah, (Eksekutif Unit Pendaftaran dan Pengurusan Rekod Mualaf) dalam temu bual dengan penulis, 2 Febuari 2015.

Dokumen rasmi, Permohonan Keluar Agama Islam (Mualaf), Tetuan Tengku Azlina, Azlan Shah dan Azman, Peguambela \& Peguamcara, Peguam Syarie, Bandar Tun Razak, Cheras, Kuala Lumpur, Januari 2015, 1-6.

Faizal Arif Tajul Ariffin. "Dahulu Mualaf Kini Murtad". Prosiding Persidangan Antarabangsa Pembangunan Muallaf 2013 (ICMUD), Kolej Universiti Islam Antarabangsa Selangor, Bangi, 2013.

Ghazali Darulsalam dan Sufean Hussin, "Metodologi Penyelidikan dalam Pendidikan Amalan dan Analisis Kajian". Kuala Lumpur: Penerbit Universiti Malaya, 2016. 
Ibn Qudamah, Abu 'Abd Allāh. Al-Mughnī. Mesir: Maktabah alQāhirah, 1969.

Koentjaraningrat. Metode Wawancara, dalam Koentjaraningrat et. al (ed), Metode-metode Penelitian Masyarakat. Cet.1, Jakarta: Penerbit PT Gramedia, 1997.

M. N Nur Suriya. "The Phenomenon of Apostasy in Malaysia: A Dtudy of Its Causes from 2003 until 2006". Dissertation, International of Islamic University Malaysia.

Mahfodz Mohamad. "Jenayah dalam Islam: Suatu Kajian Ilmiah Mengenai Hukum-hukum Hudud". Kuala Lumpur: Nurin Enterprise, 1993.

Majlis Agama Islam Pulau Pinang lwn. Siti Fatimah Tan binti Abdullah [1430H] JH 27/2; Sumanthi a/p maniam lwn. Majlis Agama Islam Wilayah Persekutuan (1434H) JH36/1, 143-159.

Mas'ud, Jabran. Al-Ra'id. Beirut: Dār al-'Ilm al-Malayin, 1986.

Mohamed Azam Mohamed Adil, "Hak Tukar Agama dalam Perlembagaan: Konflik Kebebasan Beragama dan Hukum Islam", Jurnal Syariah 11, No. 1 (2003), 29.

Mohamed Azam Mohamed Adil. "Undang-undang Murtad: Suatu Penilaian dari Perspektif Fiqh dan Undang-Undang di Malaysia dalam Kanun”, Jurnal Undang-undang Malaysia (Mac 1997), 9 Kanun (1) 1-3.

Mohd Ridhuan Tee Abdullah. Cabaran Saudara Baharu di Malaysia. Kuala Lumpur: Utusan Publication \& Distributor Sdn. Bhd., 2012.

Nazri Muslim. Islam dan Melayu dalam Perlembagaan, Tiang Seri Hubungan Etnik di Malaysia. Bangi: Universiti Kebangsaan Malaysia, 2014.

Paizah $\mathrm{Hj}$ Ismail. Undang-undang.

Perlembagaan Persekutuan, Hingga 10 Oktober 2014, (International Law Books Servis, 2014), 26.

Perlembagaan Persekutuan, Hingga 10 Oktober 2014, (International Law Books Servis, 2014), 39.

Sayyid Sabiq. Fikih Sunnah. Kuala Lumpur: Victory Agencie, 1990.

Sia Kwee Hin lwn. JAIWP [1992] 2 CLJ, 1-4; Lim Yoke Khoon lwn. Pendaftar Muallaf, Majlis Agama Islam Selangor \& Yang Lain [2006] 4 CLJ, 513-526. 